\title{
Profile of Tuberculosis in Children and Adolescent at Dr. Soetomo General Hospital Surabaya
}

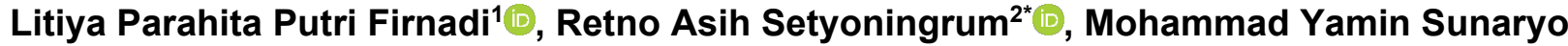 \\ Suwandi ${ }^{3}$
}

${ }^{1}$ Faculty of Medicine, Universitas Airlangga, Surabaya, Indonesia.

${ }^{2}$ Department of Pediatrics, Faculty of Medicine, Universitas Airlangga, Surabaya, Indonesia.

${ }^{3}$ Department of Radiology, Universitas Airlangga, Surabaya, Indonesia.

\section{A B S T R A C T}

Introduction: Tuberculosis is one of ten leading causes of death worldwide, including Indonesia. Indonesia is one of seven countries that causes $64 \%$ deaths due to tuberculosis. Tuberculosis is caused by Mycobacterium tuberculosis through droplet nuclei in the air. It can occur to any group age, including children and adolescent, if there is a contact history of people with tuberculosis infection. In 2016, one million children had tuberculosis and around 250,000 children died because of tuberculosis. This study aimed to know the profile of tuberculosis in children and adolescent at Dr. Soetomo General Hospital Surabaya.

Methods: This was a descriptive study using retrospective approach. Sample of this study was collected from electronic medical record provided by Dr. Soetomo General Hospital Surabaya using statistic formula of single sample for estimated population proportions of children and adolescent with tuberculosis from 2013-2017, with total samples of 149 people.

Results: There were 149 samples of children and adolescent patients with tuberculosis. Most of the children were mostly $0-4$ years old and $57 \%$ were female. $84 \%$ of the children had been immunized with BCG and classified as moderate, and $35 \%$ were under nutritional status. This study showed that $67 \%$ of the children in household contacts of adult tuberculosis patients also had tuberculosis. The most frequent symptoms of tuberculosis in children and adolescent were fever (72\%) and cough $(80 \%)$.

Conclusion: Tuberculosis in children and adolescent is more likely to occur in children than adolescent, especially children within group age of 0-4 years old. The number of pulmonary tuberculosis in children and adolescent are higher than extrapulmonary tuberculosis.

*Correspondence: retnoasih@gmail.com

JUXTA: Jurnal IImiah Mahasiswa Kedokteran Universitas Airlangga

p-ISSN: 1907-3623; e-ISSN: 2684-9453

DOI: $10.20473 /$ juxta.V13I12022.42-45

Open access under Creative Commons Attribution-ShareAlike 4.0 International License (CC-BY-SA)

\section{ARTICLE INFO}

Article history:

Received 27 October 2021

Received in revised form 3

December 2021

Accepted 28 December 2021

Available online 5 January 2022

\section{Keywords:}

Adolescent tuberculosis,

Children tuberculosis,

Tuberculosis. 


\section{Introduction}

Tuberculosis is one of ten leading causes of death worldwide. It is caused by Mycobacterium tuberculosis. It is spread when a person with active tuberculosis disease coughs or sneezes. The droplet nuclei will remain in the air for hours, hence when people inhale the droplet nuclei, it will pass quickly through alveoli. ${ }^{1}$

The response from human body to Mycobacterium tuberculosis is to activate innate immune system to kill it. For some people, their innate immune system cannot kill all of the bacteria, hence another response is to kill the bacteria which are still alive in alveoli by activating adaptive immune system. Nevertheless, if the person's immune system is weak, those bacteria will stay and can multiply inside the alveolar macrophage that can cause lesion and soon will form a ghon focus. Those Ghon focus can change into primary complex which contains ghon focus, lymphangitis, and lymphadenitis. The form of primary complex is indicated as primary tuberculosis infection. Someone with primary tuberculosis infection is the most infectious because they will spread the bacteria easily to others. $^{2}$

The response of the body to tuberculosis is by activating cellular immune system. If the immune system of the person is strong enough to fight the bacteria, the bacteria will stop multiply, but if the immune system is weak, the bacteria will stay in place or become dormant. When the bacteria becomes dormant, there is no clinical symptoms. The remaining bacteria which is still dormant in the alveoli in a few years when the immune system of the person with primary tuberculosis infection is down can become reactivated, hence the person will have tuberculosis disease. ${ }^{2}$

\section{Methods}

This was a descriptive study using retrospective approach. Data in this study was collected from children and adolescent tuberculosis patients at Dr. Soetomo General Hospital Surabaya in 2013-2017. Samples in this study were children and adolescent $(0-19$ years old) who had been diagnosed with tuberculosis based on the symptoms of such as cough, fever, night sweats, hard to breath, and loss of appetite supported by thorax X-ray. Inclusion criteria were gender, type of tuberculosis, history of BCG immunization, history of household contact, symptoms of tuberculosis, and radiology findings. The total samples of this study were 149 samples of children and adolescent with tuberculosis in 2013-2017. The samples were collected by using a statistic formula of single sample for estimated population proportions. Data collection used an electronic medical record provided by Dr. Soetomo General Hospital Surabaya, then collected 149 samples which met all of inclusion criteria. This study had obtained approval of ethical clearance from ethics commission of Faculty of Medicine, Universitas Airlangga, Surabaya (No.
0747/KEPK/X/2018). This study used Microsoft Excel in processing all of the data.

\section{Results}

This study started from June 2018 to April 2019. Data for this study was collected by using electronic medical record provided by Dr. Soetomo General Hospital Surabaya in $2013-2017$. Technique used in this study was random sampling.

Total samples of this study were 149 samples. From the sample, most were girls $(57 \%)$ and mostly aged $0-4$ years old. The number of patients with pulmonary tuberculosis $(74 \%)$ in this study was larger than extrapulmonary tuberculosis (26\%). This study divided the nutritional status into well, moderate, undernutrition, and malnutrition. The most patients were in undernutrition and malnutrition category with 34 patients each (35\% out of 96 patients) or only $64 \%$ who had nutritional status. 87 patients already had BCG immunization (84\% out of 103 total samples) or only $69 \%$ who had history of BCG immunization. This study also used an information about history of household contacts. Children tuberculosis patients who had household contacts with tuberculosis were 81 patients ( $67 \%$ out of 103 patient) or only $86 \%$ who had history of household contacts.

Table 1. Charateristics of tuberculosis in children and adolescent

\begin{tabular}{|c|c|c|c|c|c|}
\hline Charateristics & $\begin{array}{l}\text { Total } \\
\text { n (\%) }\end{array}$ & $\begin{array}{c}0-4 \\
\text { years } \\
\text { old } \\
\mathrm{n}(\%)\end{array}$ & $\begin{array}{c}5-9 \\
\text { years } \\
\text { old } \\
n(\%)\end{array}$ & $\begin{array}{c}10-14 \\
\text { years } \\
\text { old } \\
n(\%)\end{array}$ & $\begin{array}{c}15-19 \\
\text { years } \\
\text { old } \\
\mathrm{n}(\%)\end{array}$ \\
\hline \multicolumn{6}{|c|}{ Gender $(n=149,100 \%)$} \\
\hline Boys & $64(43)$ & $26(41)$ & $19(30)$ & $16(25)$ & $3(4)$ \\
\hline Girls & $85(57)$ & $35(41)$ & $29(34)$ & $18(21)$ & $3(4)$ \\
\hline \multicolumn{6}{|c|}{ Types of Tuberculosis $(n=149,100 \%)$} \\
\hline Pulmonary & $111(74)$ & $46(41)$ & $36(32)$ & $24(22)$ & $5(5)$ \\
\hline $\begin{array}{l}\text { Extra- } \\
\text { pulmonary }\end{array}$ & $38(26)$ & $14(37)$ & $13(34)$ & $10(26)$ & $1(3)$ \\
\hline \multicolumn{6}{|c|}{ Nutritional Status $(n=96,64 \%)$} \\
\hline Well & $23(24)$ & $11(48)$ & $8(35)$ & $3(13)$ & $1(4)$ \\
\hline Moderate & $5(5)$ & $3(60)$ & - & $1(20)$ & 1 (20) \\
\hline Undernutrition & $34(35)$ & $12(35)$ & $13(38)$ & $7(21)$ & $2(6)$ \\
\hline Malnutrition & $34(35)$ & $13(38)$ & $10(29)$ & $10(29)$ & $1(3)$ \\
\hline \multicolumn{6}{|c|}{ History of BCG Immunization ( $n=103,69 \%)$} \\
\hline Yes & $87(84)$ & 34 (39) & $24(28)$ & $24(28)$ & $5(6)$ \\
\hline No & 17 (16) & $7(41)$ & $7(41)$ & $2(12)$ & - \\
\hline \multicolumn{6}{|c|}{ History of Household Contacts $(n=120,86 \%)$} \\
\hline Yes & $81(67)$ & $36(44)$ & $28(35)$ & 15 (19) & $2(2)$ \\
\hline No & 39 (33) & $12(31)$ & $13(33)$ & $11(28)$ & $3(8)$ \\
\hline Total & 149 (100) & $60(40)$ & 49 (33) & $34(23)$ & $6(4)$ \\
\hline
\end{tabular}

This study also analyzed the clinical symptoms related with tuberculosis such as cough, hard to breath, fever, night sweats, and loss of appetite. The number of samples for each symptom were different. The least number of samples who had tuberculosis symptoms were patients with night sweats, only 99 patients. Cough and fever dominated this study. Most of the samples had cough (80\%) and fever 
(72\%). The least clinical symptom presented was night sweats $(33 \%)$.

Table 2. Clinical symptoms of tuberculosis in children and adolescent

\begin{tabular}{|c|c|c|c|c|c|}
\hline & $\begin{array}{l}\text { Total } \\
\text { n (\%) }\end{array}$ & $\begin{array}{c}0-4 \\
\text { years } \\
\text { old } \\
n(\%)\end{array}$ & $\begin{array}{c}5-9 \\
\text { years } \\
\text { old } \\
n(\%)\end{array}$ & $\begin{array}{c}10-14 \\
\text { years } \\
\text { old } \\
n(\%)\end{array}$ & $\begin{array}{c}15-19 \\
\text { years } \\
\text { old } \\
\mathrm{n}(\%)\end{array}$ \\
\hline \multicolumn{6}{|c|}{ Cough $(n=149,100 \%)$} \\
\hline Yes & $119(80)$ & $53(45)$ & $39(33)$ & $22(18)$ & $5(4)$ \\
\hline No & $30(20)$ & $6(20)$ & $11(37)$ & $12(40)$ & $1(3)$ \\
\hline \multicolumn{6}{|c|}{ Short of Breath $(n=135,91 \%)$} \\
\hline Ye & $64(47)$ & $28(44)$ & $22(34)$ & $11(17)$ & $3(5)$ \\
\hline No & 71 (53) & 27 (38) & 22 (31) & $19(27)$ & $3(4)$ \\
\hline \multicolumn{6}{|c|}{ Fever $(n=149,100 \%)$} \\
\hline Yes & $107(72)$ & $48(45)$ & $32(30)$ & $23(21)$ & $4(4)$ \\
\hline No & $42(28)$ & $12(29)$ & $17(40)$ & $11(26)$ & $2(5)$ \\
\hline \multicolumn{6}{|c|}{ Night Sweats $(n=99,66 \%)$} \\
\hline Yes & $33(33)$ & $10(30)$ & $13(39)$ & $8(24)$ & $2(6)$ \\
\hline No & $66(67)$ & $29(44)$ & $18(27)$ & $16(24)$ & $3(5)$ \\
\hline \multicolumn{6}{|c|}{ Loss of Appetite $(n=139,93 \%)$} \\
\hline Yes & $69(46)$ & $27(39)$ & $21(30)$ & $17(25)$ & $4(6)$ \\
\hline No & $70(47)$ & $30(43)$ & $22(31)$ & $16(23)$ & $2(3)$ \\
\hline
\end{tabular}

This study also analyzed the thorax radiology imaging. Radiology imaging in this study were consolidation, infiltrate, fibrosis, cavity, calcification, tuberculoma, pleura effusion, hilar lymphadenophaty, milliary, and normal. Number of samples who had thorax radiology imaging were 135 samples out of 149 total sample. From 135 samples, the dominant results of thorax radiology finding in this study were fibrosis $(14 \%)$, milluary $(13 \%)$, and hilar lymphadenophaty (14\%).

Table 3. Radiology imaging of tuberculosis in children and adolescent

\begin{tabular}{lccccc}
\hline & Total & $\begin{array}{c}\mathbf{0 - 4} \\
\text { years } \\
\text { old } \\
\mathbf{n}(\%)\end{array}$ & $\begin{array}{c}\mathbf{5 - 9} \\
\text { years } \\
\text { old } \\
\mathbf{n}(\%)\end{array}$ & $\begin{array}{c}\mathbf{1 0 - 1 4} \\
\text { years } \\
\text { old } \\
\mathbf{n ~ ( \% )}\end{array}$ & $\begin{array}{c}\mathbf{1 5 - 1 9} \\
\text { years } \\
\text { od } \\
\mathbf{n ~ ( \% )}\end{array}$ \\
\hline Consolidation & $4(3)$ & $2(50)$ & $1(25)$ & - & $1(25)$ \\
Infiltrate & $9(6)$ & $2(22)$ & $3(33)$ & $3(33)$ & $1(11)$ \\
Fibrosis & $40(27)$ & $23(58)$ & $9(22)$ & $6(15)$ & $2(5)$ \\
Cavity & $1(1)$ & $1(100)$ & - & - & - \\
Calcification & $3(2)$ & $1(33)$ & $1(33)$ & - & $1(33)$ \\
Tuberculoma & $10(7)$ & $6(60)$ & $3(30)$ & $1(10)$ & - \\
Pleural Effusion & $3(2)$ & $1(33)$ & $2(67)$ & - & - \\
Hilar & $21(14)$ & $4(19)$ & $5(24)$ & $10(48)$ & $2(9)$ \\
lymphadenopathy & & & & & $2(10)$ \\
Milliary & $20(13)$ & $6(30)$ & $7(35)$ & $5(25)$ & $2(31)$ \\
$\begin{array}{l}\text { Pulmonary } \\
\text { Infammation }\end{array}$ & $13(9)$ & $6(46)$ & $4(31)$ & $3(23)$ & - \\
Normal & $11(7)$ & $4(36)$ & $6(55)$ & $1(9)$ & - \\
\hline
\end{tabular}

Discussion

According to World Health Organization (WHO), globally males have higher risk to be infected and passed away due to tuberculosis than females. Nevertheless, in this study, the number of female children tuberculosis patients was larger than male. Some other studies have similar results with this study, in which the number of females was larger than males. In a study performed by Bolursaz, et al., from 203 children with tuberculosis, 117 patients were females. ${ }^{3}$ The difference result of this study and $\mathrm{WHO}$ was because the number of samples in this study which is not comparable with the number of samples globally. From the type of tuberculosis, in this study the result of children tuberculosis was dominated by pulmonary tuberculosis. One of the reasons why the case of pulmonary tuberculosis in this study was larger than extrapulmonary was because the lungs became port d'entrée of more than $98 \%$ case of tuberculosis infection because of the size of the bacteria which made it easier to pass through the alveoli. ${ }^{1}$

Nutritional status of the samples was mostly undernutrition and malnutrition. Higher risk for tuberculosis can be caused by the change of immune system that cannot protect the body from Mycobacterium tuberculosis or because the interaction between $\mathrm{T}$ lymphocyte and macrophage are disrupted due lack of nutrition. ${ }^{4}$ Most of the samples already had BCG immunization. Nevertheless, according to WHO, BCG immunization cannot avoid primary infection of tuberculosis. ${ }^{5}$ History of household contact is related with tuberculosis. Children who have history of contact with adult tuberculosis patient has higher risk to have tuberculosis. ${ }^{6}$

In this study, the most clinical symptoms were cough and fever. Fever is the systemic effect from the body. It is caused by process of sitokin release from macrophage to fight Mycobacterium tuberculosis. It also becomes the most common symptom in children. ${ }^{7}$ In a study conducted by Jahromi and Mood, it showed that a lot of children with tuberculosis had cough and fever. ${ }^{8}$

Abnormality thorax imaging which happens commonly in children with tuberculosis is lymphadenopathy (90-95\%) and only happens $43 \%$ in adults. Sites of lymphadenopathy which commonly affected are hilar and paratracheal. ${ }^{9}$ In this study, the number of patients with fibrosis was larger than others. Fibrosis also commonly appears in patients with tuberculosis and indicated for treatment for latent tuberculosis. ${ }^{10}$

\section{Conclusion}

Based on the results of the study, it is concluded that the prevalence of children with tuberculosis is larger than in adolescent. Subjects of this study were mostly 0-4 years old and the number of pulmonary tuberculosis was larger than extra-pulmonary tuberculosis.

\section{Acknowledgments}

The author expresses gratitude to all relatives who had helped to motivate, support, giving guidance, as well as directions which allows the author to finish this study. Special acknowledgement to Dr. Retno Asih Setyoningrum, dr., Sp.A(K) as the first mentor and M. Yamin Sunaryo S., $\mathrm{dr}$., Sp.Rad(K) as second mentor who were willing to spend their precious time to help the author finishing this study. 
Also Dr. Laksmi Wulandari, dr., Sp.P(K), FCCP as the examiner. The author also expresses her gratitude to all lecturers in Faculty of Medicine, Universitas Airlangga who have shared their knowledge, the author's parents and sibling who always have the author's back.

\section{CONFLICT OF INTEREST}

The author stated there is no conflict of interest in this study.

\section{REFERENCES}

1. World Health Organization. Global tuberculosis report 2015, 20th ed. World Health Organization, https://apps.who.int/iris/handle/10665/191102 (2015).

2. Amin Z, Bahar A. Buku Ajar Ilmu Penyakit Dalam. 6th ed. Jakarta: Pusat Penerbitan Departemen IImu Penyakit Dalam Fakultas Kedokteran Universitas Indonesia, 2010.

3. Bolursaz MR, Lotfian F, Aghahosseini F, et al. Journal of Comprehensive Pediatrics JOURNAL OF COMPREHENSIVE PEDIATRICS Official Quarterly Journal of Iranian Society of Pediatrics CiteScore 2020: 0.7 SIGN IN REGISTER
SUPPORT Characteristics of Tuberculosis among Children and Adolescents at a Referral . J Compr Pediatr 2016; 7: e59822.

4. Gupta KB, Gupta R, Atreja A, et al. Tuberculosis and Nutrition. Lung India 2009; 26: 9-16.

5. World Health Organization. Recommendations to Assure the Quality, Safety and Efficacy of BCG Vaccines, Annex 3, TRS No 979. World Health Organization, https://www.who.int/publications/m/item/trs-979annex-3-bcg-vax (2013).

6. Lienhardt C, Sillah J, Fielding K, et al. Risk Factors for Tuberculosis Infection in Children in Contact with Infectious Tuberculosis cases in the Gambia, West Africa No Title. Pediatrics 2003; 111: e608-14.

7. Esposito S. Tuberculosis in Children. Mediterr J Hematol Infect Dis; 5. Epub ahead of print 2013. DOI: https://doi.org/10.4084/mjhid.2013.064.

8. Jahromi MK, Sharifi-Mood B. Pulmonary Tuberculosis in Children. Int J Infect 2014; 1: e21116.

9. Skoura E, Zumla A, Bomanji J. Imaging in Tuberculosis. Int J Infect Dis 2015; 32: 87-93.

10. Peiró JS, Galvão ML de S, Gómez MNA. Inactive Fibrotic Lesions versus Pulmonary Tuberculosis with Negative Bacteriology. Arch Bronconeumol 2014; 50: 484-9. 